\title{
Pembuktian Penyalahgunaan Wewenang Dalam Perkara Tindak Pidana Korupsi Pengadaan Barang dan Jasa
}

\section{"Evidence of Abusing Authority in Criminal Procurement Corruption of Goods and Services"}

\author{
Ahmad Rustan Syamsuddin 1 \\ 1Fakultas Hukum Universitas Muhammadiyah Kendari, Sulawesi Tenggara, Indonesia. E-mail: ahmadrustan.law@gmail.com
}

\begin{tabular}{|c|}
\hline Info Artikel \\
\hline $\begin{array}{l}\text { Kata Kunci: } \\
\text { Korupsi; } \\
\text { Pembuktian; } \\
\text { Penyalahgunaan } \\
\text { Wewenang. }\end{array}$ \\
\hline $\begin{array}{lr}\text { Cara Mengutip } & \text { (APA } \\
\text { Citation Style): } & \\
\text { Syamsuddin, } & \text { Ahmad } \\
\text { Rustan. } & (2020) . \\
\text { "Pembuktian } & \\
\text { Penyalahgunaan } & \\
\text { Wewenang } & \text { Dalam } \\
\text { Perkawa Tindak } & \text { Pidana } \\
\text { Korupsi Pengadaan } \\
\text { Barang dan Jasa". } \\
\text { Jambura Law, JALREV } 2 \\
\text { (2): } 161-181\end{array}$ \\
\hline
\end{tabular}

\begin{abstract}
Abstrak
Korupsi pada sektor pengadaan barang dan jasa pemerintah semakin meningkat dari tahun ke tahun baik dari segi jumlah kasusnya maupun dari segi nilai kerugian negara yang ditimbulkan. Korupsi dalam proses pengadaan barang dan jasa pada umumnya terjadi karena adanya penyalahgunaan wewenang dari penyelenggara negara yang terlibat dalam proses pengadaan mulai dari perencanaan sampai pada diterimanya barang dan jasa oleh Penggguna Anggaran (PA) atau Kuasa Pengguna Anggaran (KPA). Pada umumnya terpidana kasus korupsi pada sektor pengadaan didakwa dengan menggunakan Pasal 3 jo Pasal 18 ayat (1) huruf b Undang-Undang Republik Indonesia Nomor 31 Tahun 1999 tentang Pemberantasan Tindak Pidana Korupsi sebagaimana diubah dengan Undang-Undang Republik Indonesia Nomor 20 Tahun 2001 tentang perubahan atas Undang-Undang Republik Indonesia Nomor 31 tahun 1999 tentang Pemberantasan Tindak Pidana Korupsi. Salah satu unsur yang wajib dibuktikan oleh Jaksa Penuntut Umum pada persidangan adalah unsur penyalahgunaan wewenang disamping unsur yang lain juga perlu dibuktikan khususnya berkenaan dengan unsur adanya kerugian negara secara nyata. Dengan berlakunya Undang-Undang Republik Indonesia Nomor 30 Tahun 2014 Tentang Administrasi Pemerintahan, terdapat disharmonisasi perundang-undangan terkait kompetensi dan prosedur pembuktian penyalahgunaan wewenang.
\end{abstract}


Article Info

\section{Keywords: \\ Corruption; Evidence; Abusing Authority.}

How to cite (APA Citation
Style):
Syamsuddin, Ahmad
Rustan. (2020). "Evidence
of Abusing Authority in
Criminal Procurement
Corruption of Goods and
Services". Jambura Law,
JALREV2 (2): 161-181

(C) 2020 - Syamsuddin, Ahmad Rustam Under the license CC BY-SA 4.0

\begin{abstract}
Corruption in the procurement sector of government goods and services has increased from year to year both in terms of the number of cases and in terms of the value of the state losses incurred. Corruption in the process of procurement of goods and services generally occurs due to abuse of authority from state administrators involved in the procurement process from planning to receipt of goods and services by the Budget User (PA) or the Budget User Authority. Generally, convicted of corruption case in the procurement sector was charged using Article 3 in conjunction with Article 18 paragraph (1) letter b of Republic Indonesian Law at Number 31 of 1999 concerning Eradication of Corruption Acts as amended by the Law of the Republic of Indonesia Number 20 of 2001 concerning Amendments Republic Indonesian Law at Number 31 of 1999 concerning Eradication of Corruption. One of the elements that must be proven by the Public Prosecutor at the trial is the element of abusing authority in addition to the other elements also need to be proven, especially with regard to the element of real statelosses. With the enactment of Republic Indonesian Law at Number 30 of 2014 concerning Government Administration, there is a dishamony of legislation related to competence and procedure for proving the abusing authority.
\end{abstract}

\section{Pendahuluan}

Tujuan bernegara salah satunya adalah mewujudkan kesejahteraan umum. ${ }^{1}$ Dalam pembukaan Undang-Undang Dasar Negara Republik Indonesia Tahun 1945 (UUD 45) menjelaskan bahwa" ... untuk membentuk suatu Pemerintahan Negara Indonesia yang melindungi segenap bangsa Indonesia dan seluruh tumpah darah Indonesia dan untuk memajukan kesejahteraan umum, mencerdaskan kehidupan bangsa ${ }^{2}$, dan ikut melaksanakan ketertiban dunia yang berdasarkan kemerdekaan, perdamaian abadi, dan keadilan sosial"3 kita dapat memahami bahwa Indonesia diarahkan untuk menjadi negara yang sejahtera (welfare state). Walfare state ${ }^{4}$ atau yang lazim disebut sebagai negara kesejahteraan merupakan gagasan ideal bagaimana suatu negara diberikan kekuasaan yang besar untuk menyejahterakan warga negaranya. Implementasinya, negara dituntut untuk melakukan percepatan pembangunan nasional yang berdasarkan pada konsep Negara demokrasi konstitusional (constitutional democratie

1 M. Darin Arif Mu'allifin. (2016)". "Hubungan Konstitusi Dengan Tugas Dan Fungsi Negara”. Jurnal AHKAM, 4 (1): 166

2 Oman Sukmana. (2016). “Konsep dan Desain Negara Kesejahteraan (Welfare State)”. Jurnal Sosial Politik (Sospol), 2 (1): 104

3 Fence M. Wantu dan Ahmad. (2019). "Mekanisme Koordinasi dan Singkronisasi Lembaga Kementerian Negara: Suatu Praksis Menuju Kabinet Yang Efektif". Jurnal AHKAM, 15 (2): 69-70

4 Oman Sukmana. Op Cit. Hlm. 104 
state $)^{5}$ dalam rangka pemenuhan layanan publik yang berkualitas dengan berbagai kebijakan yang dijalankan oleh organ negara. Negara sebagai organisasi kekuasaan dalam menjalankan tugas dan wewenangnya mengacu pada instrument hukum administrasi sebagai tolok ukur keabsahannya.

Pembangunan merupakan langkah strategis untuk mewujudkan tujuan nasional tersebut, baik itu pembangunan manusianya, maupun pembangunan fisiknya. Dalam implementasinya, terhadap pembangunan fisik berupa pengadaan sarana dan prasarana, tentu harus diimbangi dengan tata kelola pengadaan barang/jasa yang baik, tetapi kegiatan pengadaan barang/jasa pemerintah bukan bertujuan untuk menghasilkan barang/jasa yang profit oriented, melainkan lebih bersifat memberikan pelayanan kepada masyarakat (publik service). Untuk itu, pemerintah membutuhkan barang/jasa dalam upayanya setiap saat guna meningkatkan pelayanan publik. ${ }^{6}$

Pengadaan barang/jasa juga merupakan sarana mewujudkan visi dan misi pemerintah baik di pusat maupun di daerah termasuk didalamnya pemerintah desa. Kegiatan ini menjadi sangat penting dalam rangka menyerap anggaran yang telah ditetapkan pemerintah melalui Anggaran Pendapatan dan Belanja Negara (APBN), Anggran Pendapatan dan Belanja Daerah (APBD) Provinsi, maupun APBD Kabupaten/Kota, serta APBDes. Realisasi anggaran melalui belanja barang dan belanja modal (investasi)/belanja langsung, yang pelaksanaannya dilakukan melalui pengadaan barang/jasa dari tahun ke tahun umumnya selalu meningkat ${ }^{7}$. Berdasarkan Pasal 3 ayat (1) Undang-undang Republik Indonesia Nomor : 17 Tahun 2003 tentang Keuangan Negara mengatur bahwa "Keuangan Negara dikelola secara tertib, taat pada peraturan perundang-undangan, efesien, ekonomis, efektif, transparan, dan dapat bertanggung jawab dengan memperhatikan rasa keadilan dan kepatutan".

5 Ahmad dan Novendri M. Nggilu. (2019). "Denyut Nadi Amandemen Kelima UUD 1945 melalui Pelibatan Mahkamah Konstitusi sebagai Prinsip the Guardian of the Constitution”.Jurnal Konstitusi, 16 (4): 798

6 Eman Suparman. (2014). "Aspek Hukum Perdata dalam Pelaksanaan Pengadaan Barang/Jasa Pemerintah pada Rancangan Undang- undang TentangPengadaan Barang/Jasa”. Makalah pada Seminar Pembahasan Teknis Mengenai Masukan untuk Naskah Akademis RUU Pengadaan dikaitkan dengan Hukum Perdata dan Tipikor; Diselenggarakan oleh Lembaga Kebijakan Pengadaan Barang/Jasa Pemerintah (LKPP) RI; Jakarta, Kamis, 20 November 2014.

7 Kemenkeu. "Pengumuman Realisasi APBN". Dilansir dari www.kemenkeu.go.id, 
Pelaksanaan pengadaan barang dan jasa selama ini banyak menimbulkan persoalan dimulai sejak perencanaan hingga serah terima pekerjaan. Tidak sedikit pelaku pengadaan telah terjerat dengan kasus korupsi termasuk pengadaan pada tingkat pemerintahan desa. Pada umumnya, pelaku dijerat dengan Pasal 3 jo Pasal 18 ayat (1) huruf b Undang-Undang Republik Indonesia Nomor 31 Tahun 1999 tentang Pemberantasan Tindak Pidana Korupsi (UU No. 31 Tahun 1999) sebagaimana diubah dengan Undang-Undang Republik Indonesia Nomor 20 Tahun 2001 tentang perubahan atas Undang-Undang Republik Indonesia Nomor 31 tahun 1999 tentang Pemberantasan Tindak Pidana Korupsi. ${ }^{8}$

Berdasarkan data Komisi Pemberantasan Korupsi (KPK) pada tiga tahun terakhir (2017-2019) kasus korupsi pada sektor pengadaan yang ditangani oleh KPK sebanyak 35 perkara yang menempati urutan kedua dan kasus penyuapan berada pada urutan pertama dengan jumlah kasus sebanyak 220 perkara. ${ }^{9}$. Data ini menunjukkan bahwa, sektor pengadaan barang/ jasa merupakan area yang rawan terjadinya penyimpangan yang berpotensi menimbulkan tindak pidana korupsi pada setiap tahapan mulai dari perencanaan (identifikasi kebutuhan), persiapan, dan tahap pelaksanaan (sampai pada tahap serah terima pekerjaan).

Salah satu perkara kasus pengadaan yang menjadi obyek kajian penulis adalah perkara Hady Wintani, SE, Sekretaris Camat Maro Sebo Ulu, Batanghari telah divonis oleh majelis hakim Tipikor Jambi berdasarkan Putusan Nomor 46/Pid.SusTPK/2019/PN.Jmb ${ }^{10}$ dalam kasus pengadaan jaringan internet di Kecamatan Maro Sebo Ulu tahun anggaran 2017. Dalam amar putusannya, terdakwa dinyatakan terbukti secara sah dan meyakinkan melakukan tindak pidana korupsi memperkaya diri sendiri sebagaimana Dakwaan Subsidair Pasal 3 jo Pasal 18 ayat (1) huruf b UU No 31 tahun 1999 tentang pemberantasan tindak pidana korupsi sebagaimana diubah dengan UU No 20 tahun 2001 tentang perubahan atas UU No 31 tahun 1999 tentang pemberantasan tindak pidana korupsi. Dalam amar putusan dinyatakan :

8 Iriyanto Tiranda, et al. (2019). "Konsep Ideal Penanganan Perkara Tindak Pidana Korupsi Pungutan Liar Berdasarkan Asas Peradilan”. Jambura Law Review, JALREV 1 (2): 123

9 Komisi Pemberantasan Korupsi. "Data Statistik Penindakan KPK". Dilansir dari www.kpk.go.id, diakses pada tanggal 31 Desember 2019).

10 Direktori Putusan Mahkamah Agung Republik Indonesia, Dilansir dari www.putusan.mahkamahagung.go.id 
"Menjatuhkan pidana kepada terdakwa Hady Wintany, S.E., oleh karena itu dengan pidana penjara selama 1 tahun, serta denda sejumlah Rp50.000.000,(lima puluh juta rupiah) dengan ketentuan apabila denda tersebut tidak dibayar diganti dengan pidana kurungan selama 1 (satu) bulan".

"Menghukum Terdakwa Hady Wintani, S.E., untuk membayar Uang Pengganti sejumlah Rp.20.000.000,00 (dua puluh juta rupiah) dengan ketentuan apabila terdakwa tidak membayar uang pengganti dalam waktu 1 (satu) bulan setelah putusan pengadilan berkekuatan hukum tetap, maka harta bendanya disita jaksa dan dilelang untuk menutupi uang pengganti tersebut, dalam hal terdakwa tidak mempunyai harta benda yang mencukupi untuk membayar uang pengganti tersebut, maka dipidana selama 1(satu) bulan"

Dalam perkara ini, Jaksa Penuntut Umum (JPU) berkewajiban membuktian pasal yang didakwakan yakni Pasal 3 UU No 31 tahun 1999 tentang pemberantasan tindak pidana korupsi sebagaimana diubah dengan UU No 20 tahun 2001 tentang perubahan atas UU No 31 tahun 1999 tentang pemberantasan tindak pidana korupsi. Unsur yang wajib dibuktikan adalah :

a. setiap orang,

b. menguntungkan diri sendiri atau orang lain atau suatu korporasi,

c. menyalahgunakan kewenangan, kesempatan atau sarana yang ada padanya karena jabatan atau kedudukan

d. merugikan keuangan negara atau perekonomian negara,

Pada penelitian ini, penulis menfokuskan pada pembuktian penyalahgunaan wewenang yang didakwakan oleh Jaksa Penuntut Umum kepada Terdakwa Hady Wintany, SE. dikaitkan dengan berlakunya Undang-Undang Republik Indonesia Nomor 30 Tahun 2014 Tentang Administrasi Pemerintahan (UU AP) yang didalamnya mengatur legalitas tindakan dari aspek wewenang, syarat/prosedur, substansi agar terciptnya suatu mekanisme "Tranparansi". ${ }^{11}$ Oleh karenanya, pada penelitian ini menawarkan konsep hukum terkait prosedur pembuktian penyalahgunaan wewenang dalam perkara tindak pidana korupsi pegadaan barang dan jasa pemerintah yang melibatkan pejabat publik.

\section{Rumusan Masalah}

Sesuai dengan uraian pada pendahuluan tersebut di atas, maka permasalahan dalam penelitian ini adalah bagaimana prosedur pembuktian penyalahgunaan wewenang

11 Nuvazria Achir. (2020). “Anotasi Normatif Terhadap Peraturan Daerah Tentang Transparansi”. Jambura Law Review, JALREV 2 (1): 98 
setelah berlakunya Undang-Undang Republik Indonesia Nomor 30 Tahun 2014 Tentang Administrasi Pemerintahan?

\section{Metode}

Mencermati isu hukum yang dikaji dalam penelitian ini, maka dapatlah dipastikan bahwa penelitian termasuk dalam penelitian hukum normatif dengan menggunakan 2 (dua) metode pendekatan untuk menjawab permasalahan sesuai dengan rumusan masalah yang telah ditetapkan sebelumnya yaitu: ${ }^{12}$ Pendekatan perundang-undangan (statute approach dan Pendekatan kasus (case approach) Putusan Pengadilan Tindak Pidana Korupsi Pada Pengadilan Negeri Jambi Nomor 46/Pid.Sus-TPK/2019/PN.Jmb.

\section{Sumber dan Cara Memeperoleh Kewenangan}

Istilah wewenang atau kewenangan disejajarkan dengan "authority" dalam Bahasa Inggris dan "bevoegdheid" dalam Bahasa Belanda. Authority dalam Black S Law Dictionary diartikan sebagai legal power; a right to command or to act; the right and power of public officers to require obedience to their orders lawfully issued in scope of their public duties ${ }^{13}$ (Kewenangan atau wewenang merupakan kekuasaan hukum, hak untuk memerintah atau bertindak; hak atau kekuasaan pejabat publik untuk mematuhi aturan hukum dalam lingkup melaksanakan kewajiban publik). Phillipus M. Hadjon menguraikan bahwa wewenang sebagai konsep hukum publik sekurang-kurangnnya terdiri dari 3 (tiga) komponen, yaitu pengaruh, dasar hukum, dan komformitas hukum. Komponen pengaruh ialah bahwa penggunaan wewenang dimaksudkan untuk mengendaikan perilaku subjek hukum. Komponen dasar hukum bahwa wewennag itu selalu harus dapat ditunjuk dasar hukumnya. Komponen konformitas mengandung makna adanya standar wewenang yaitu standar umum (semua jenis wewenang) dan standar khusus (untuk jenis wewenang tertentu) ${ }^{14}$.

Seiring dengan pilar utama Negara hukum, yaitu asas legalitas (legaliteitbeginsel atau het beginsel van wetmatigheid van bestuur), maka berdasarkan prinsip ini tersirat

12 Peter Mahmud Marzuki. (2014). "Penelitian Hukum, Edisi Revisi”. Jakarta: Prenadamedia Group. hlm. 136-158.

13 Henry Campbell Black. (1910). "Black"S Law Dictionary”, Second Edition, ST Paul: West Publishing, hlm. 133

14 Phillipus M. Hadjon. (1997). “Tentang Wewenang”. Yuridika No. 5 \& 6 Tahun XII, SeptemberDesember. hlm. 1 
bahwa wewenang pemerintahan "berasal dari peraturan perundang-undangan"15, artinya sumber wewenang bagi pemerintah adalah peraturan perundang-undangan yang pada dasarnya "pembentukan peraturan perundang-undangan untuk memberikan kepastian hukum dan memenuhi rasa keadilan".16 Secara teoritik, kewenangan yang bersumber dari peraturan perundang-undangan tersebut diperoleh melalui tiga cara yaitu atribusi, delegasi, dan mandat. Indroharto mengatakan bahwa pada atribusi terjadi pemberian wewenang pemerintahan yang baru oleh suatu ketentuan dalam peraturan perundang-undangan. Disini dilahirkan atau diciptakan suatu wewenang baru ${ }^{17}$. Pada delegasi terjadilah pelimpahan suatu wewenang yang telah ada oleh Badan atau Jabatan Tata Usaha Negara yang telah memperoleh wewenang pemerintahan secara atributif kepada Badan atau jabatan Tata Usaha Negara lainnya. Jadi suatu delegasi selalu didahului oleh adanya atribusi wewenang ${ }^{18}$.

Mengenai atribusi, delegasi dan mandat ini H.D. Van Wijk/Willem Konijnenbelt mengemukakan sebagai berikut :

a. Atributie : toekenning van een besturesbevoegheid door een wetgever aan een besturursorgaan, (atribusi adalah pemberian wewenang pemerintah oleh pembuat undang-undang kepada organ pemerintah).

b. Delegatie : overdracht van een het ene bestuursorgaan aan een ander, (delegasi adalah pelimpahan wewenang pemerintahan dari suatu organ pemerintahan kepada organ pemerintahan lainnya).

c. Mandaat : een bestuursorgaan laat zijn bevoegheid names hem uitoefenen door een ander, (mandat terjadi ketika organ pemerintahan mengizinkan kewenangannya dijalankan oleh organ lain atas namanya). ${ }^{19}$

Dalam kaitan dengan konsep atribusi, delegasi, mandat itu dinyatakan oleh J.G. Brouwer dan A.E. Schilder ${ }^{20}$, bahwa;

a. With atribution, power is granted to an administrative authority by an independent legislative body.The power is initial (originair), which is to say

15 Muhaimin. (2019). “Restoratif Justice Dalam Penyelesaian Tindak Pidana Ringan”. Jurnal Penelitian Hukum DE JURE, 19 (2): 193

16 Taufik H. Simatupang. (2019). "Mendudukkan Konsep Executive Review Dalam Sistem Hukum Ketatanegaraan Indonesia”. Jurnal Penelitian Hukum DE JURE, 19 (2): 218.

17 Ridwan HR. (2011). "Hukum Administrasi Negara”. Jakarta : Raja Grafindo Persada, hlm. 101.

18 Ibid, hlm. 91

19 Ibid, hlm. 102

20 Brouwer.J.G dan Schilder. (1998). "A Survey of Dutch Administrative Law" Nijmegen: Ars Aequi Libri. Hlm. 16-18. dalam Tatiek Sri Djatmiati. (2004). “Prinsip Izin Usaha Industri di Indonesia”. hlm. 65. 
that is not derived from a previously existing power.The legislative body creates independent and previously non-existent powers and assigns them to an authority.

b. Delegations are the tansfer of an acquired attribution of power from one administrative authority to another, so that the delegate (the body that has acquired the power) can exercise power in its own name.

c. With mandate, there is no transfer, but the mandate giver (mandans) assigns power to the other body (mandataris) to make decisions or take action in its name.

Penjelasan lebih lanjut menurut J.G. Brouwer dalam Tatiek Sri Djatmiati ${ }^{21}$ pada atribusi, kewenangan diberikan kepada suatu badan legislatif yang independen. Kewenangan ini adalah asli, yang tidak diambil dari kewenangan yang ada sebelumnya. Badan legislatif menciptakan kewenangan mandiri dan bukan perluasan kewenangan sebelumnya dan memberikannya kepada yang berkompeten. Delegasi ditransfer dari kewenanagan atribusi dari satu badan administrasi yang satu kepada yang lainnya, sehingga delegator (badan yang telah memberikan kewenangan) dapat menguji kewenangan tersebut atas namanya.

Pada mandat tidak terdapat suatu transfer kewenangan, tetapi pemberi mandat (mondous) memberikan kewenangan pada badan yang lain (mandataris) untuk membuat suatu keputusan atau mengambil satu tindakan atas namanya. Terdapat perbedaan yang mendasar antara kewenangana atribusi dan delegasi. Pada atribusi kewenangan yang siap ditransfer, tidak demikian dengan delegasi. Dalam kaitan dengan asas legalitas kewenangan tidak dapat didelegasikan secara besar-besaran, akan tetapi hanya mungkin dibawah kondisi bahwa peraturan hukum menentukan mengenai kemungkinan delegasi. ${ }^{22}$

Berdasarkan Pasal 11 Undang-Undang Republik Indonesia No. 30 Tahun 2014 Tentang Administrasi Pemerintahan mengatur (UU AP) bahwa Kewenangan diperoleh melalui Atribusi, Delegasi, dan/atau Mandat. Selanjutnya pada Pasal 12 ayat (1) UU AP mengatur bahwa Badan dan/atau Pejabat Pemerintahan memperoleh Wewenang melalui Atribusi apabila:

21 Tatiek Sri Djatmiati. (2004). Disertasi: “Prinsip Izin Usaha Industri di Indonesia. Surabaya: Program Pascasarjana Ilmu Hukum Universitas Airlangga. hlm. 65.

22 Ibid. 
a. diatur dalam Undang-Undang Dasar Negara Republik Indonesia Tahun 1945 dan/atau undang-undang;

b. merupakan Wewenang baru atau sebelumnya tidak ada; dan

c. Atribusi diberikan kepada Badan dan/atau Pejabat Pemerintahan.

Berdasarkan ketentuan tersebut, maka yang perlu digaris bawahi adalah syarat kewenangan melalui atribusi jika kewenangan tersebut sebelumnya telah diatur melalui Undang-Undang Dasar Negara Republik Indonesia Tahun 1945 (UUD 1945) dan/atau undang-undang. Selanjutnya, Pasal 12 ayat (2) UU AP mengatur bahwa Badan dan/atau Pejabat Pemerintahan yang memperoleh Wewenang melalui Atribusi, tanggung jawab Kewenangan berada pada Badan dan/atau Pejabat Pemerintahan yang bersangkutan.

Pasal 12 ayat (3) UU AP menentukan bahwa kewenangan Atribusi tidak dapat didelegasikan, kecuali diatur di dalam (UUD 1945) dan/atau undang-undang. Pada Pasal 13 ayat (2) UU AP mengatur bahwa Badan dan/atau Pejabat Pemerintahan memperoleh Wewenang melalui Delegasi apabila:

a. diberikan oleh Badan/Pejabat Pemerintahan kepada Badan dan/atau Pejabat Pemerintahan lainnya;

b. ditetapkan dalam Peraturan Pemerintah, Peraturan Presiden, dan/atau Peraturan Daerah; dan

c. merupakan wewenang pelimpahan atau sebelumnya telah ada.

Kewenangan yang didelegasikan kepada Badan dan/atau Pejabat Pemerintahan tidak dapat didelegasikan lebih lanjut, kecuali ditentukan lain dalam peraturan perundangundangan. (Pasal 13 ayat 3). Dalam hal ketentuan peraturan perundang-undangan menentukan lain sebagaimana dimaksud pada ayat (3), Badan dan/atau Pejabat Pemerintahan yang memperoleh Wewenang melalui Delegasi sebagaimana dimaksud pada ayat (2) dapat mensubdelegasikan Tindakan kepada Badan dan/atau Pejabat Pemerintahan lain dengan ketentuan:

a. dituangkan dalam bentuk peraturan sebelum Wewenang dilaksanakan;

b. dilakukan dalam lingkungan pemerintahan itu sendiri; dan

c. paling banyak diberikan kepada Badan dan/atau Pejabat Pemerintahan 1 (satu) tingkat di bawahnya. 
Badan dan/atau Pejabat Pemerintahan yang memberikan Delegasi dapat menggunakan sendiri Wewenang yang telah diberikan melalui Delegasi, kecuali ditentukan lain dalam ketentuan peraturan perundang-undangan. (Pasal 13 ayat 5). Dalam hal pelaksanaan Wewenang berdasarkan Delegasi menimbulkan ketidakefektifan penyelenggaraan pemerintahan, Badan dan/atau Pejabat Pemerintahan yang memberikan pendelegasian Kewenangan dapat menarik kembali Wewenang yang telah didelegasikan (Pasal 13 ayat 6). Badan dan/atau Pejabat Pemerintahan yang memperoleh Wewenang melalui Delegasi, tanggung jawab Kewenangan berada pada penerima Delegasi.

Badan dan/atau Pejabat Pemerintahan memperoleh Mandat apabila,

a. ditugaskan oleh Badan dan/atau Pejabat Pemerintahan di atasnya; dan

b. merupakan pelaksanaan tugas rutin.

Pejabat yang melaksanakan tugas rutin sebagaimana dimaksud pada ayat (1) huruf b terdiri atas:

a. pelaksana harian yang melaksanakan tugas rutin dari pejabat definitif yang berhalangan sementara; dan

b. pelaksana tugas yang melaksanakan tugas rutin dari pejabat definitif yang berhalangan tetap.

Badan dan/atau Pejabat Pemerintahan dapat memberikan Mandat kepada Badan dan/atau Pejabat Pemerintahan lain yang menjadi bawahannya, kecuali ditentukan lain dalam ketentuan peraturan perundang-undangan. Badan dan/atau Pejabat Pemerintahan yang menerima Mandat harus menyebutkan atas nama Badan dan/atau Pejabat Pemerintahan yang memberikan Mandat.

Badan dan/atau Pejabat Pemerintahan yang memberikan Mandat dapat menggunakan sendiri Wewenang yang telah diberikan melalui Mandat, kecuali ditentukan lain dalam ketentuan peraturan perundang-undangan. Badan dan/atau Pejabat Pemerintahan yang memperoleh Wewenang melalui Mandat tanggung jawab Kewenangan tetap pada pemberi Mandat. Berdasarkan Pasal 14 ayat (7) UU AP mengatur bahwa : Badan dan/atau pejabat pemerintahan yang memperoleh kewenangan melalui mandat tidak berwenang mengambil keputusan dan/atau tindakan yang bersifat strategis yang berdampak pada perubahan status hukum pada aspek organisasi, kepegawaian, dan 
alokasi anggaran". Selanjutnya, pelimpahan wewenang melalui mandat mensyaratkan pejabat yang menyerahkan kewenangan harus dalam kondisi berhalangan sementara atau berhalangan tetap yang wujudnya melalui pelaksana tugas atau pelaksana harian yang otoritasnya hanya melaksanakan tugas rutin saja.

Apabila dikaitkan dengan tindakan yang dilakukan oleh terdakwa Hady Wintani, SE yang menggunakan kedudukannya untuk terlibat secara langsung dalam pengadaan barang/jasa di tingkat desa, tidak terdapat sumber kewenangan yang tepat untuk melegalisasi tindakannya baik secara atribusi, delegasi, maupun mandat. Sehingga tepatlah dikatakan bahwa tindakan yang tanpa didasarkan pada peraturan perundangundangan merupakan tindakan penyalahgunaan wewenang yang muaranya tenteu saja adalah tindakan/perbuatan yang "melawan hukum", adanya kesalahan dan adanya kerugian yang ditimbulkan. ${ }^{23}$ Tindakan tersebut kembali menamba daftar panjang Indeks Persepsi Korupsi negara Indonesia yang belum kunjung membaik. ${ }^{24}$

\section{Pembuktian Penyalahgunaan Wewenang}

Menurur J. H. Nieuwenhuis ${ }^{25}$, tanggung gugat timbul karena adanya perbuatan melanggar hukum (onrehmatige daad) dan merupakan penyebab (oorzaak) timbulnya kerugian. Sedangkan pelakunya bersalah (schuld), maka orang itu harus bertanggung gugat atas kerugian tersebut. Tanggung gugat menurut Agus Yuda Hernoko adalah suatu rangkaian untuk menanggung kerugian yang diakibatkan karena kesalahan atau resiko. Hal tersebut sejalan dengan pandangan Y. Sogar Simammora bahwa tanggung gugat tidak hanya berupa ganti kerugian, namun juga pemulihan kepada keadaan semula 26 .

Instrumen hukum yang utama untuk mewujudkan pemerintah yang bersih adalah hukum administrasi. Peran hukum administrasilah yang diharapkan mampu mencegah maladministrsi, karena hal ini berkaitan dengan penggunaan wewenang, oleh karena itu pemahaman hukum administrasi dan pembangunan hukum

23 Teresia Din. (2019). "Pertanggungjawaban Notaris Terhadap Akta Otentik Terindikasi Tindak Pidana". Jurnal Penelitian Hukum DE JURE, 19 (2):174

24 Idul Rishan. (2019). "Batas Konstitusional Penggunaan Hak Angket terhadap Komisi Pemberantasan Korupsi”. Jurnal Konstitusi, 16 (3): 646

25 J. H. Nieuwenhuis. (1985). "Hoofdstuken verbintenissenrecht", terjemahan Djasadin Saragih, Surabaya. hlm. 118

26 Siti Kotijah. (2011). "Tanggung Gugat Hukum Perusahaan Akibat Pengelolaan Pertambangan Batu bara". Jurnal Yuridika 26 (3): 10. 
administrasi mutlak diperlukan. Kenyataan menunjukkan saat ini masih sangat minim dan banyak yang salah mengartikan hukum administrasi. Penanganan maldministrasi serta penyalahgunaan wewenang dan tindak pidana korupsi masih fokus pada aspek hukum pidana, dan sedikit sekali perhatian terhadap hukum administrasi ${ }^{27}$. Padahal sanksi administrasi merupakan konsekuensi negatif dari pelanggaran terhadap kewajiban dan tugas yang bersifat administrasi dan legal. Sanksi administrasi adalah salah satu jenis sanksi hukum, yang ditetapkan untuk memastikan penghormatan terhadap ketentuan hukum. ${ }^{28}$

Tindakan hukum yang dilakukan oleh penyelenggara Negara dan pemerintahan baik yang disengaja maupun akibat kelalaian yang menimbulkan kerugian Negara dapat diselesaikan melaui mekanisme administrasi sebelum dilakukan tuntutan secara pidana. Hal ini penting dilakukan untuk pemulihan kerugian keuangan Negara tanpa proses pidana yang membutuhkan biaya yang cukup besar mulai dari biaya penyelidikan dan penyidikan, penuntutan, proses peradilan, sampai pada pemidanaan.

Dalam perkara tindak pidana dikenal asas ultimum remedium merupakan istilah hukum yang biasa dipakai dan diartikan sebagai penerapan hukuman yang merupakan sanksi pamungkas (terakhir) dalam penegakan hukum ${ }^{29}$. Demikian halnya dikemukakan oleh Didik Endro Purwoleksono bahwa makna Ultimum remedium, hukum pidana atau sanksi pidana dipergunakan manakala sanksi-sanksi yang lain sudah tidak berdaya. Dengan perkataan lain, dalam suatu undang-undang sanksi pidana dicantumkan sebagai sanksi yang terakhir, setelah sanksi perdata, maupun sanksi administratif ${ }^{30}$. Doktrin ultimum remedium berarti bahwa penggunaan hukum pidana hanya dapat dilakukan apabila instrumen hukum lain seperti hukum

27 Philipus M.Hadjon. (2011). "Kisi-kisi Hukum Administrasi Dalam Konteks Tindak Pidana Korupsi”, dalam Buku Hukum Administrasi Dan Tindak Pidana Korupsi. Yogyakarta: Gadjah Mada University Press. hlm. 20

28 Fauzi Syam, et. al. (2019). "Pengujian Keputusan Pemberhentian Tidak Dengan Hormat Sebagai Pegawai Negeri Sipil Di Peradilan Administrasi”. Jurnal Penelitian Hukum DE JURE, 19 (1): 52. Lihat juga dalam Sri Nur Hari Susanto. (2019). "Karakter Yuridis Sanksi Hukum Administrasi: Suatu Pendekatan Komparasi," Adminitrative Law \& Governance Journal, 2 (1): 126-142

29 Sudikno Mertokusumo. (2019). "Penemuan Hukum Sebuah Pengantar". Jakarta: Liberty. hlm. 128

30 Didik Endro Purwoleksono. (2016). "Hukum Pidana". Surabaya: Airlangga University Press. hlm. 8 
administrasi atau hukum perdata tidak efektif. ${ }^{31}$ Perkataan ultimum remedium untuk pertama kali dipergunakan oleh Menteri kehakiman belanda yaitu Mr. Modderman di depan parlemen negeri Belanda untuk menjawab pertanyaan salah seorang anggota parlemen yaitu Mr. Mckay, yang mengatakan bahwa ia telah gagal menemukan suatu dasar hukum mengenai perlunya suatu penjatuhan hukuman bagi seseorang yang telah melakukan suatu pelanggaran ${ }^{32}$

Dalam perkara Hady Wintani, SE, penulis tidak melihat ada upaya untuk menyelesaikan perkara ini baik dari aspek administrasi maupun perdata. Tindakan yang dilakukan oleh Hady Wintani, SE dalam kedudukannya sebagai sekretaris camat pada Kecamatan Maro Sebo Ulu berdasarkan Keputusan Bupati Batang Hari Nomor : 821.23/ 23 / BPKSDMD tanggal 03 Februari 2017 tentang pengangkatan kembali (pengukuhan) Pegawai Negeri Sipil dalam jabatan administrator dilingkungan pemerintah Kabupaten Batang Hari yang merangkap sebagai ketua Tim Evaluasi berdasarkan Keputusan Camat Maro Sebo Ulu Nomor 27 Tahun 2017 tanggal 7 Januari 2017 tentang Pembentukan Tim Evaluasi Rancangan Peraturan Desa tentang APBDES dalam Wilayah Kecamatan Maro Sebo Ulu tahun 2017 apabila ditinjau dari teori kewenangan maka tindakan terdakwa yang memerintahkan kepada masing-masing Kepala Desa dalam Wilayah Kecamatan Maro Sebo Ulu untuk memasukkan anggaran pengadaan jaringan internet dalam APBDes senilai Rp. 15.000.000,- (lima belas juta rupiah) merupakan tindakan melampaui kewenangan yang bertentangan dengan peraturan perundang-undangan. Terdakwa juga terlibat secara langsung untuk melakukan pengadaan barang/jasa yang diluar kewenangannya serta melakukan pengadaan yang tidak sesuai dengan yang direncanakan berupa jaringan internet yang mengakibatkan adanya kerugian keuangan negara.

Tindakan tersebut bertentangan dengan Pasal 17 ayat (1) UU AP bahwa : "Badan dan/atau Pejabat Pemerintahan dilarang menyalahgunakan kewenangan". Selanjutnya pada Pasal 18 ayat (1) huruf c diatur bahwa : Badan dan/atau Pejabat Pemerintahan dikategorikan melampaui Wewenang sebagaimana dimaksud dalam Pasal 17 ayat (2)

31 Beby Suryani Fithri. (2017). “Asas Ultimum Remedium Terhadap Anak Yang Berkonflik Dengan Hukum Dalam Rangka Perlindungan Anak". Jurnal Mercatoria, 10 (1): 83

32 Mas Putra Zenno Januarsyah. (2017). "Penerapan Prinsip Ultimum Remedium dalam Tindak Pidana Korupsi (Kajian Putusan Nomor 2149 K/PID.SUS/2011”. Jurnal Yudisial, 10 (3): 267 
huruf a apabila Keputusan dan/atau Tindakan yang dilakukan: bertentangan dengan ketentuan peraturan perundang-undangan".

Pada Pasal 19 ayat (1) UU AP mengatur bahwa "Keputusan dan/atau Tindakan yang ditetapkan dan/atau dilakukan dengan melampaui Wewenang sebagaimana dimaksud dalam Pasal 17 ayat (2) huruf a dan Pasal 18 ayat (1) serta Keputusan dan/atau Tindakan yang ditetapkan dan/atau dilakukan secara sewenang-wenang sebagaimana dimaksud dalam Pasal 17 ayat (2) huruf c dan Pasal 18 ayat (3) tidak sah apabila telah diuji dan ada Putusan Pengadilan yang berkekuatan hukum tetap". Berdasarkan ketentuan tersebut, menghendaki agar ada pengujian secara khusus melalui pengadilan terkait sah atau tidaknya tindakan yang dilakukan oleh badan/pejabat karena adanya penyalahgunaan wewenang.

Selanjutnya pada Pasal 20 UU AP mengatur bahwa :

(1) Pengawasan terhadap larangan penyalahgunaan Wewenang sebagaimana dimaksud dalam Pasal 17 dan Pasal 18 dilakukan oleh aparat pengawasan intern pemerintah.

(2) Hasil pengawasan aparat pengawasan intern pemerintah sebagaimana dimaksud pada ayat (1) berupa:

a. tidak terdapat kesalahan;

b. terdapat kesalahan administratif; atau

c. terdapat kesalahan administratif yang menimbulkan kerugian keuangan negara.

(3) Jika hasil pengawasan aparat intern pemerintah berupa terdapat kesalahan administratif sebagaimana dimaksud pada ayat (2) huruf b, dilakukan tindak lanjut dalam bentuk penyempurnaan administrasi sesuai dengan ketentuan peraturan perundang-undangan.

(4) Jika hasil pengawasan aparat intern pemerintah berupa terdapat kesalahan administratif yang menimbulkan kerugian keuangan negara sebagaimana dimaksud pada ayat (2) huruf c, dilakukan pengembalian kerugian keuangan negara paling lama 10 (sepuluh) hari kerja terhitung sejak diputuskan dan diterbitkannya hasil pengawasan.

(5) Pengembalian kerugian negara sebagaimana dimaksud pada ayat (4) dibebankan kepada Badan Pemerintahan, apabila kesalahan administratif sebagaimana dimaksud pada ayat (2) huruf c terjadi bukan karena adanya unsur penyalahgunaan Wewenang

(6) Pengembalian kerugian negara sebagaimana dimaksud pada ayat (4) dibebankan kepada Pejabat Pemerintahan, apabila kesalahan administratif sebagaimana dimaksud pada ayat (2) huruf c terjadi karena adanya unsur penyalahgunaan Wewenang.

Substansi yang diatur dalam Pasal 20 UU AP tersebut di atas merupakan upaya administrasi yang dapat dilakukan untuk pembuktian penyalagunaan wewenang serta 
prosedur pengawasan terkait adanya penyalahgunaan wewenang dalam penyelenggaraan pelayanan publik. Terdapat atribusi kewenangan kepada Aparat Pengawas Internal Pemerintah (APIP) untuk menguji keabsahan tindakan aparatur pemerintah. Jika APIP menemukan adanya kesalahan administratif yang menimbulkan kerugian keuangan negara maka prosedur pertama yang perlu dilakukan adalah rekomendasi kepada pejabat yang melakukan penyalahgunaan wewenang untuk melakukan pengembalian kerugian keuangan negara paling lama 10 (sepuluh) hari kerja terhitung sejak diputuskan dan diterbitkannya hasil pengawasan. Dalam praktiknya, memungkinkan badan/pejabat yang diduga melakukan penyalahgunaan wewenang menolak rekomendasi yang dihasilkan oleh APIP dengan berbagai argumentasi hukum yang dibangun. Maka prosedur selanjutnya adalah pembuktian penyalahgunaan wewenang melalui pengadilan Tata Usaha Negara (PTUN).

Berdasarkan Pasal 21 UU AP mengatur bahwa:

(1) Pengadilan berwenang menerima, memeriksa, dan memutuskan ada atau tidak ada unsur penyalahgunaan Wewenang yang dilakukan oleh Pejabat Pemerintahan.

(2) Badan dan/atau Pejabat Pemerintahan dapat mengajukan permohonan kepada Pengadilan untuk menilai ada atau tidak ada unsur penyalahgunaan Wewenang dalam Keputusan dan/atau Tindakan.

(3) Pengadilan wajib memutus permohonan sebagaimana dimaksud pada ayat (2) paling lama 21 (dua puluh satu) hari kerja sejak permohonan diajukan.

(4) Terhadap putusan Pengadilan sebagaimana dimaksud pada ayat (3) dapat diajukan banding ke Pengadilan Tinggi Tata Usaha Negara.

Berdasarkan ketentuan tersebut, maka pembuktian penyalagunaan wewenang merupakan kompetensi absolud peradilan Tata Usaha Negara. Dengan demikian, maka unsur tindak pidana korupsi pada Pasal 3 UU No. 31 tahun 1999 tentang Pemberantasan Tindak Pidana Korupsi bahwa :

"Setiap orang yang dengan tujuan menguntungkan diri sendiri atau orang lain atau suatu korporasi, menyalahgunakan kewenangan, kesempatan, atau sarana yang ada padanya karena jabatan atau kedudukan atau sarana yang ada padanya karena jabatan atau kedudukan yang dapat merugikan keuangan negara atau perekonomian negara, dipidana dengan pidana penjara seumur hidup atau pidana penjara paling singkat 1 (satu) tahun dan paling lama 20 (dua puluh) tahun dan atau denda paling sedikit Rp. 50.000.000 (lima puluh juta rupiah) dan paling banyak Rp. 1.000.000.000,00 (satu miliar rupiah)". 
Unsur Pasal ini khususnya unsur penyalahgunaan wewenang tidak berdiri sendiri lagi setelah berlakunya Pasal 21 UU AP. Akan tetapi, harus dibuktikan terlebih dahulu unsur penyalahgunaan wewenang yang dilakukan oleh penyelenggara Negara tersebut melalui PTUN kemudian dapat diproses lebih lanjut melalui peradilan Tipikor, sehingga dalam hal terjadi kesalahan prosedur dalam penerbitan keputusan/tindakan, menjadi pelanggaran administrasi yang konsekuensinya keputusan TUN tersebut dapat dibatalkan atau menjadi obyek sengketa TUN. Yang menjadi wewenang Pengadilan TUN adalah sengketa terkait keputusan (beschikking) yang bersifat konkret, individual dan final ${ }^{33}$. Gugatan diajukan secara tertulis atas keputusan tersebut melalui Pengadilan Tata Usaha Negara (PTUN) dengan atau tanpa disertai tuntutan ganti rugi atau rehabilitasi, sebagaimana diatur dalam Pasal 53 UndangUndang No. 5 Tahun 1986, terakhir UU No. 9 Tahun 2004 tentang Peradilan Tata Usaha Negara, yaitu:

1) Seseorang atau badan hukum perdata yang merasa kepentingannya dirugikan oleh suatu Tata Usaha Negara dapat mengajukan gugatan tertulis kepada pengadilan yang berwenang yang berisi tuntutan agar Keputusan Tata Usaha Negara yang disengketakan itu dinyatakan batal atau tidak sah, dengan atau tanpa disertai tuntutan ganti rugi atau rehabilitasi.

2) Alasan-alasan yang dapat digunakan dalam gugatan sebagaimana dimaksud dalam angka (1) adalah:

a. Keputusan Tata Usaha Negara bertentangan dengan peraturan perundang undangan yang berlaku. Suatu Keputusan Tata Usaha Negara dinilai bertentangan dengan peraturan perundang-undangan yang berlaku jika:

1. Keputusan Tata Usaha Negara yang disengketakan itu bertentangan dengan peraturan perundang-undangan yang bersifat prosedural/formal.

2. Bertentangan dengan ketentuan-ketentuan dalam peraturan perundang-undanganyang bersifat material/substansial.

3. Dikeluarkan oleh Pejabat atau Badan Tata Usaha Negara yang tidak berwenang.

b. Penyalahgunaan wewenang

Badan atau Pejabat Tata Usaha Negara pada waktu mengeluarkan keputusan Tata Usaha Negara menggunakan wewenangnya untuk tujuan lain dari maksud diberikannya wewenang tersebut.

c. Berbuat sewenang-wenang

33 Ahmad Sukarja. (2014). "Hukum Tata Negara dan Hukum Administrasi Negara Dalam Perspektif Fikih Siyasah”. Jakarta Timur: Sinar Grafika. hlm. 243. 
Badan atau pejabat Tata Usaha Negara pada waktu mengeluarkan atau tidak mengeluarkan Keputusan Tata Usaha Negara yang disengketakan, setelah mempertimbangkan semua kepentingan yang tersangkut dengan keputusan itu, seharusnya tidak sampai pada pengambilan atau tidak pengambilan keputusan tersebut.

Penegakan hukum tidak hanya dilihat dari apa yang telah diputus oleh hakim, akan tetapi bagaiman penegakan hukum tersebut dilakukan sesuai dengan prosedur dan batas-batas kewenangan oleh aparatur penegak hukum. Prosedur hukum yang dimaksud adalah penerapan asas ultimum remedium dimana pemidanaan merupakan prosedur terakhir dari penegakan hukum setelah upaya administrasi dan upaya perdata telah dilakukan. Abdul latif ${ }^{34}$ mengemukakan bahwa penegakan hukum dan keadilan tidak boleh dilakukan hanya dengan pendekatan dari segi represif (penindakan) belaka, karena penegakan hukum dan keadilan sesungguhnya juga meliputi upaya preventif (pencegahan) tidak terjadinya pelanggaran hukum berupa sewenang-wenang dalam negara hukum.

Upaya adminitrasi ini penting dilakukan agar nilai-nilai keadilan untuk semua pihak dapat dirasakan. Dalam kasus Hady Wintani, SE, sesuai dengan hasil pembuktian di pengadilan, nilai kerugian negara setelah dikembalikan oleh terdakwa tersisa sebesar Rp. 20.000.000,- (dua puluh juta rupiah) sementara biaya yang dikeluarkan negara untuk melakukan proses hukum mulai dari tahap penyelidikan, penyidikan, penuntutan, sampai pada biaya yang harus dikeluarkan negara ketika ditempatkan pada lembaga pemasyarakatan untuk menjalankan pidananya tentu jauh lebih besar dari kerugian negara akibat perbuatan terdakwa. Sehingga upaya penegakan hukum untuk memulihkan kerugian negara justru jauh lebih besar disbanding kerugian negara yang ditimbulkan dari pelaku kejahatan. Realitas ini menunjukkan asas kemanfaatan yang menjadi salah satu tujuan hukum tidak tercapai.

Aspek lain yang perlu dipertimbangkan adalah, kedudukan terdakwa sebagai Aparatur Sipil Negara. Berdasarkan ketentuan dalam UU No. 5 Tahun 2004 tentang Aparatur Sipil Negara mengatur bahwa PNS dapat diberhentikan tidak dengan hormat apabila terbukti melakukan tindak pidana kejahatan jabatan atau tindak pidana kejahatan

34 H. Abdul Latif. (2014). "Hukum Administrasi Dalam Praktik Tindak Pidana Korupsi”. Jakarta: Prenada Media Group. HIm. 174-175 
yang ada hubungannya dengan jabatan dan/atau pidana umum. Hal ini tertuang dalam Pasal 87 ayat (4) huruf b Undang-Undang Nomor 5 Tahun 2014 tentang Aparatur Sipil Negara (UU ASN) mengatur bahwa : (4) PNS diberhentikan tidak dengan hormat karena : b. dihukum penjara atau kurungan berdasarkan putusan pengadilan yang telah memiliki kekuatan hukum tetap karena melakukan tindak pidana kejahatan jabatan atau tindak pidana kejahatan yang ada hubungannya dengan jabatandan/atau pidana umum.

Disisi lain dijelaskan kembali pada Pasal 250 huruf b dan Pasal 252 Peraturan Pemerintah No.11 Tahun 2017 tentang Manajemen Pegawai Negeri Sipil yakni sebagai berikut :

Pasal 250

PNS diberhentikan tidak dengan hormat apabila:

a. dipidana dengan pidana penjara atau kurungan berdasarkan putusan pengadilan yang telah memiliki kekuatan hukum tetap karena melakukan tindak pidana kejahatan Jabatan atau tindak pidana kejahatan yang ada hubungannya dengan Jabatan dan/atau pidana umum;

Pasal 252

Pemberhentian sebagaimana dimaksud dalam Pasal 250 huruf b dan huruf d dan Pasal 251 ditetapkan terhitung mulai akhir bulan sejak putusan pengadilan atas perkaranya memiliki kekuatan hukum tetap.

Berdasarkan ketentuan tersebut, maka terpidana kasus penyalahgunaan wewenang atau kejahatan yang ada kaitannya dengan jabatan bagi penyelenggara negara apabila pengadilan memutus telah terbukti melakukan kejahatan penyalahgunaan wewenang, berapapun vonisnya tidak dapat menghindarkan diri dari sanksi administrasi pemberhentian tidak dengan hormat sebagai ASN. Hal ini menunjukkan adanya penghukuman berlapis yang akan dihadapi oleh terpidana selain sanksi pidana penjara, pidana denda, pidana pengganti, maka terpidana juga akan berhadapan dengan sanksi administrasi berupa pemberhentian sebagai ASN. Sehingga model pembuktian penyalahgunaan wewenang antara UU No. 31 Tahun 1999 dengan UU No. 30 Tahun 2014 perlu harmonisasi dengan prioritas pada UU No. 30 Tahun 2014. Hal ini sejalan dengan asas lex posteriori derogat legi priori agar terwujud prosedur penegakan hukum yang adil. 


\section{Kesimpulan}

Pembuktian penyalahgunaan wewenang setelah berlakunya Pasal 21 Undang-Undang Republik Indonesia Nomor 30 Tahun 2014 Tentang Administrasi Pemerintahan merupakan kompetensi absolud Peradilan Tata Usaha Negara. Sehingga Pengadilan Tipikor tidak berwenang memeriksa dan memutus perkara khusus berkaitan dengan dakwaan Pasal penyalahgunaan wewenang yang diatur dalam Pasal 3 Undang-Undang Republik Indonesia Nomor 31 Tahun 1999 Tentang Pemberantasan Tindak Pidana Korupsi sebagaimana diubah dengan Undang-Undang Republik Indonesia Nomor 20 Tahun 2001 tentang Perubahan Atas Undang-undang Republik Indonesia Nomor 31 Tahun 1999 Tentang Pemberantasan Tindak Pidana Korupsi. Dengan demikian perkara Nomor 46/Pid.Sus-TPK/2019/PN.Jmb atas nama terpidana Hady Wintani, SE disimpulkan mengalami cacat wewenang mengadili serta bertentangan dengan asas ultimum remidium. Prosedur pembuktian penyalahgunaan wewenang seharusnya dimulai dengan upaya administrasi melalui pengawasan APIP. Jika hasil pengawasan APIP tidak dapat dilaksanakan, maka dilanjutkan dengan pembuktian penyalahgunaan wewenang dan dapat disertai dengan tuntutan ganti rugi jika terdapat kerugian bagi para pihak. Selain itu, upaya gugatan perdata juga salah satu alternatif yang dapat digunakan bagi para pihak yang merasa dirugikan akibat tindakan yang dilakukan oleh badan/pejabat TUN sebelum dilakukan pemidanaan.

\section{Referensi}

Achir, Nuvazria. (2020). "Anotasi Normatif Terhadap Peraturan Daerah Tentang Transparansi". Jambura Law Review, JALREV 2 (1).

Ahmad dan Nggilu, Novendri M. (2019). “Denyut Nadi Amandemen Kelima UUD 1945 melalui Pelibatan Mahkamah Konstitusi sebagai Prinsip the Guardian of the Constitution." Jurnal Konstitusi, 16 (4).

Black, Henry Campbell. (1910). "Black'S Law Dictionary”, Second Edition, ST Paul: West Publishing.

Din, Teresia. (2019). "Pertanggungjawaban Notaris Terhadap Akta Otentik Terindikasi Tindak Pidana”. Jurnal Penelitian Hukum DE JURE, 19 (2).

Djatmiati, Tatiek Sri. (2004). "Prinsip Izin Usaha Industri di Indonesia". Disertasi Program Pascasarjana Ilmu Hukum Universitas Airlangga, Surabaya. 
Fithri, Beby Suryani. (2017). "Asas Ultimum Remedium Terhadap Anak Yang Berkonflik Dengan Hukum Dalam Rangka Perlindungan Anak". Jurnal Mercatoria, 10 (1).

Hari Susanto, Sri Nur. (2019). "Karakter Yuridis Sanksi Hukum Administrasi: Suatu Pendekatan Komparasi”. Adminitrative Law \& Governance Journal, 2 (1).

HR, Ridwan (2011). "Hukum Administrasi Negara”. Jakarta: Raja Grafindo Persada.

Januarsyah, Mas Putra Zenno. (2017). "Penerapan Prinsip Ultimum Remedium dalam Tindak Pidana Korupsi (Kajian Putusan Nomor 2149 K/PID.SUS/2011)”. Jurnal Yudisial, 10 (3).

Kotijah, Siti. (2011). "Tanggung Gugat Hukum Perusahaan Akibat Pengelolaan Pertambangan Batu bara". Jurnal Yuridika, 26 (3).

Latif, H. Abdul. (2014). "Hukum Administrasi Dalam Praktik Tindak Pidana Korupsi”. Jakarta : Prenada Media Group.

Marzuki, Peter Mahmud. (2016). “Penelitian Hukum” Edisi Revisi. Jakarta: Prenadamedia Group.

Mertokusumo, Sudikmo. (2009). "Penemuan Hukum Sebuah Penganta”. Jakarta: Liberty.

M. Hadjon, Phillipus. (1997). “Tentang Wewenang”. Jurnal Yuridika, 11 (5-6).

, (2011). “Kisi-kisi Hukum Administrasi Dalam Konteks Tindak Pidana Korupsi” Dalam Buku Hukum Administrasi Dan Tindak Pidana Korupsi, Yogyakarta: Gadjah Mada University Press.

Muhaimin. (2019). "Restoratif Justice Dalam Penyelesaian Tindak Pidana Ringan". Jurnal Penelitian Hukum DE JURE, 19 (2).

Mu'allifin, M. Darin Arif. (2016). "Hubungan Konstitusi Dengan Tugas Dan Fungsi Negara". Jurnal AHKAM, 4 (1).

Nieuwenhuis, J.H, (1985). "Hoofdstuken verbintenissenrecht", terjemahan Djasadin Saragih. Surabaya.

Purwoleksono, Didik Endro. (2014). "Hukum Pidana”. Surabaya: Airlangga University Press.

Rishan, Idul. (2019). "Batas Konstitusional Penggunaan Hak Angket terhadap Komisi Pemberantasan Korupsi”. Jurnal Konstitusi, 16 (3). 
Syam, Fauzi. et. al. (2019). "Pengujian Keputusan Pemberhentian Tidak Dengan Hormat Sebagai Pegawai Negeri Sipil Di Peradilan Administrasi”. Jurnal Penelitian Hukum DE JURE, 19 (1).

Simatupang, Taufik H. (2019). "Mendudukkan Konsep Executive Review Dalam Sistem Hukum Ketatanegaraan Indonesia”. Jurnal Penelitian Hukum DE JURE, 19 (2).

Sukmana, Oman. 2016. Konsep dan Desain Negara Kesejahteraan (Welfare State). Jurnal Sosial Politik (Sospol). 2 (1)

Suparman, Eman, [2014]. “Aspek Hukum Perdata dalam Pelaksanaan Pengadaan Barang/Jasa Pemerintah pada RancanganUndang- undangTentangPengadaan Barang/Jasa. Makalah pada Seminar Pembahasan Teknis Mengenai Masukan untuk Naskah Akademis RUU Pengadaan dikaitkan dengan Hukum Perdata dan Tipikor". Diselenggarakan oleh Lembaga Kebijakan Pengadaan Barang/Jasa Pemerintah (LKPP) RI; Jakarta, Kamis, 20 November 2014.

Sukarja, Ahmad. [2014]. "Hukum Tata Negara dan Hukum Administrasi Negara Dalam Perspektif Fikih Siyasah”. Jakarta Timur: Sinar Grafika.

Tiranda, Iriyanto, et al. (2019). "Konsep Ideal Penanganan Perkara Tindak Pidana Korupsi Pungutan Liar Berdasarkan Asas Peradilan”. Jambura Law Review, JALREV 1 (2).

Wantu, Fence M. dan Ahmad. (2019). "Mekanisme Koordinasi dan Singkronisasi Lembaga Kementerian Negara: Suatu Praksis Menuju Kabinet Yang Efektif". Jurnal AHKAM. Volume 15 (2). 